DOI: $10.18775 /$ ijied.1849-7551-7020.2015.44.2004

\title{
Online Reputation of Selected Car Brands
}

\author{
${ }^{1}$ František Pollák, ${ }^{2}$ Peter Dorčák, ${ }^{3}$ Peter Markovič, ${ }^{4}$ Nella Svetozarovová \\ 1,4 Faculty of Management, University of Prešov, Prešov, Slovakia \\ 2,3 Faculty of Business Management, University of Economics in Bratislava, Slovakia
}

\begin{abstract}
The paper discusses the issue of reputation, more specifically the ways and methods of its measurements in selected entities operating in the automotive sector. A thorough multifactor analysis of reputation in the virtual world of the Internet was conducted on a specific sample of entities/ subjects - Top 10 car brands by market share on Slovak market. Using careful statistical testing relationships between factors were examined in order to identify and describe facts affecting online reputation of those entities in the hypercompetitive market environment of the Internet. The findings identified by the analysis of online environment were compared to traditional success indicators as market share. The results of analysis thus providing a comprehensive view on the issue of the online reputation in the widest possible range of perspectives.
\end{abstract}

Keywords: Reputation, On-line reputation, Reputation determinant, Reputator, Internet, TOR, Automotive

\section{Introduction}

Reputation is an extremely important factor for gaining and strengthening consumer trust and confidence in the virtual as well as real world (Helm et al, 2011; Gottschalk, 2011; Maryška, Doucek, Novotný, 2012; Maryška, Doucek, Kunstova, 2012; Pollák, et al, 2016; Dorčák, Markovič, Pollák, 2017). Trust building is a long and arduous process and includes feelings, impressions and experiences of people who came into contact with the given compa ny / business entity. The Internet has changed the way we perceive reputation (Stecet al., 2014). In the past reputation of a company or individual was the result of hard work and also well-guarded. At present, all it takes to destroy good reputation is just a few mouse clicks. There are many people who are trying to destroy someone's reputation deliberately, like envious competitors, unsuccessful job applicants or dissatisfied clients. The Internet gives them the opportunity to constantly interfere with online reputation of a company using Google or entire site which are flooded with false or modified information. If a company is thoroughly prepared, it can defend itself from such attacks on its reputation. The Internet is hard to ignore, it is not a trend that would disappear, but rather its strength is growing. Even though some companies do not care about their reputation, everyone else is watching it - employees, potential customers, competitors (Soviar, 2011). Available information thus change everyone else's view of the company (Fertik, Thomson, 2010). Online reputation management is the process of ensuring that the right information appears when people search for it in browsers such as Yahoo!, Bing, Google or social networks Facebook, Twitter, Linked In and the like. The idea behind online reputation management is to minimize the negative content and promote flattering content. To achieve this goal, it is necessary to monitor the search engines and social networks and do what we can to minimize the number of negative comments (Stradtman, 2012). Negative content can be pushed back by creating enough positive content so it would appear that negative content just vanished. Furthermore, it is sometimes possible to get a competent administrator access and remove such a content. While access to the actual analysis, let's look in more detail at the basic characteristics of research problems. The following instructions should be followed as closely as possible. 


\subsection{Reputation in the Online Environment, Online Reputation Management}

Many Slovak and foreign authors (Kanika, 2016; Sasko, 2014; Pollák, Belovodská, 2015; Delina, 2014; Delina, Dráb, 2009; Delina, Tkáč, 2010) argue that the concept of online reputation may cover many aspects ranging from organic presence in the search results, through traditional channels of marketing communication to its presence in its own virtual channels via social media. Reputation is thus the result of the activities carried out by a business entity on the Internet. This concept also includes interaction with customers and their reactions (Fill, 2009). Today, there is no need to question why the online reputation is vitally important, but rather how to analyze the current state of online reputation and how to get started with its active management (Marsden, 2013). In the following three points, we will point out a few facts that are crucial for active online branding:

- the number of potential online customers is increasing,

- availability of information on the Internet,

- need to keep the brand under control.

It is an objective fact that the number of potential online customers is increasing. More and more companies are becoming aware of the fact that online presence is a necessity. Consumers enjoy fast access and favourable prices of services and goods on the Internet. It is likely that people soon will buy online goods and services mainly because of their convenience and not only for affordable prices. Therefore, online presence and reputation are critical for attracting new customers. Online references and reviews have a similar effect as recommendations from customers. Overlooking online reputation may mean the difference between success and failure or bankruptcy (Leboff, 2011). Another key factor speaking in favor of online presence is the ever-increasing availability of information. Nowadays many people are familiar with social networks which also feature online reviews. It is quite possible that a lot of things we do offline will become online matters. Therefore, it is important to remember that online and offline worlds are closely linked and our business activities in the offline world will be eventually reflected in our online reputation. Online reputation management is one of the best possible ways to find out the current status of a business entity's corporate brand. It is more than possible that our customers will leave a review on the Internet at some point of time. In addition to web platforms and websites, it is necessary to control all the "other" media associated with our brand like interaction with customers, fans or even competitors (Pollák, 2015; Dorčák, Štrach, Pollák, 2015; Soviar, Vodák, 2012). The article provides an insight into the active reputation management in the online environment using a thorough analysis of one of the available methodologies. Moreover, the article also evaluates data, identifies common background and provides recommendations regarding the subject matter, namely top-selling brand of cars operating on the Slovak market.

\section{Aims and Methods}

The main objective of the paper is to present chosen option for measuring online reputation of selected entities operating in the automotive sector with an aim to increase their competitiveness through a better understanding of the basic determinants of effective management of online reputation. Based on the current state of the issue theoretical knowledge and bases were accumulated, that provide knowledge base for the subsequent empirical research. A thorough multifactor analysis of reputation in the virtual world of the Internet was conducted on a specific sample of entities - Top 10 Slovak bestselling car brands of the year 2016 by tier market share (in the table indicated in \% as "MCS", or MCS score). For the purpose of this research, we used modified multi-factor sentiment analysis on which we would like to demonstrate model option for measuring total online reputation (TOR) of selected entities. Methodology of the modified multi-factor analysis (Pollák et al, 2016) of the total online reputation TOR (Pollák, 2015), brings more variability in its application on a broader spectrum of subjects than standard multi-factor analysis introduced by Sasko (2014). Moreover, it also 
brings a comprehensive look at the reputation of the given entity relative to the total possible reputation expressed as a percentage. Methodology used in the TOR index uses $\mathrm{n}$-factors.

The first step analyses the sentiment of the first 10 results on Google. As for the number of groups, the standard is at least three groups: 1st group: name of the entity, 2nd group: name of the entity + the first most important keyword from the field the entity operates in, in our case it was "Slovensko" (taking into account the language competencies of the customers of the selected market). The number of groups is not particularly limited. Quantification is then ensured by unifying the scores into the percentage form. This is based on the assumption that within a single group the entity may receive a maximum score of 155 points - the ratio 1 point $=0.645 \%$. For purpose of our analysis with 2 groups, the entity may receive a maximum score of 310 points - the ratio 1 point $=0.32 \%$.

The second step identifies the determinants of online reputation, the reputators. Reputator can be any determinant that can objectively affect the perceived online reputation of the entity, while its value can be quantified as a percentage (Pollák, 2015). Normally, these are important webpages, catalogues or social networks that can significantly affect the reputation of the entity. Given the various business fields entities operate in, reputation determinants cannot be clearly defined in advance. In terms of advantage quantification, it is possible to approach individual reputation determinants by calculation of reputators' competitive score - the amount of users (fans / customers / followers) the particular entity has relative to the sum of all tested subjects. The result serves as a basis for calculating the percentage of the reputators' competitive score (CS) of the particular entity. In other words, reputator competitive strength of the particular subject can be calculated as the size ratio of its own tribe indicated as the total number of subject followers/ fans/ subscribers/ to the total amount of tribes of all tested subjects.

In the third step, we can calculate the total advantage of the entity's online reputation with regard to its pre-defined competitors, as follows: Standard equation (Pollák, 2015) features specific determinants of online reputation and their weight. The basic reputation determinant is the ASA percentage score. The equation allows us to take into account any number of other reputation determinants. For the calculation itself, it is necessary to determine the weights of individual reputation determinants which are normally determined depending on the subject and target market. If the weight of individual reputation determinants is not known in advance, the simplified formula for calculating the overall online reputation is as follows:

Where:

TOR- Total online reputation in \%

Ri - Reputator (\% score based on a given i-th determinant of online reputation

RASA - Reputator ASA (\% score based on the advanced sentiment analysis)

$\mathrm{n}$ - Number of indicators

In this case, the value of the overall online reputation of an entity is the arithmetic mean of individual indicators (partial scores of individual reputators). Relations among factors (online reputation score based on the advanced sentiment analysis compared to the indices of reputation offered by the main Internet players, such as Facebook and YouTube provide as a part of their ratings) were examined in thorough statistical testing using non-parametrical methods, such as Kendall rank coefficient, in order to identify and describe basic facts affecting online reputation of selected entities in the hypercompetitive market environment of the Internet. 


\section{Results and Discussion}

Each of the set of selected entities, in this case top 10 Slovak bestselling car brands of the year 2016 , try to shape their reputation both within real and virtual world through their management. For the purposes of our research, we focused on the virtual world of the Internet.

\subsection{Overview Table of Partial Score}

Using the advanced sentiment analysis (ASA), we calculated partial score presenting the power of online reputation of entities based on the nature of the first 10 Google search results (personalization of results was removed by utilization of online proxy anonymizer). Google and its search results are, however, only one of many ways in which potential customers can access relevant information. Considering the previous research in the field of automotive industry, we identified the following other determinants of online reputation (reputators) of automotive entities, in particular:

- Facebook (total number of fans of the official global profile);

- YouTube (total number of subscribers of the official global profile).

Each of these reputators has its own system which determines the overall score. But, basically, all of them operate with a certain tribe of the customers (followers, fans, subscribers). For the purposes of further analysis, scores of partial reputators were unified to the parameter which we named competitive strength, hereafter referred to as CS and converted into a percentage. Before we analyse the results by statistical testing, it is necessary to expound the specific values and partial score for the analysed subjects through the overview table.

The following table presents partial results - measured values of individual determinants/score of partial reputators of online reputation/ as w ell as the score of total (overall) online reputation:

Table 1: Overall (Total) online reputation

\begin{tabular}{|l|l|l|l|l|l|l|l|}
\hline Rank & $\begin{array}{l}\text { Car brand/ } \\
\text { Result } \\
\text { sentiment }\end{array}$ & $\begin{array}{l}\text { ASA } \\
(\mathbf{\%})\end{array}$ & $\begin{array}{l}\text { FCS } \\
(\%)\end{array}$ & $\begin{array}{l}\text { YCS } \\
(\%)\end{array}$ & $\begin{array}{l}\text { Number of } \\
\text { pages } \\
\text { indexed by } \\
\text { Google }\end{array}$ & $\begin{array}{l}\text { MCS score } \\
(\%)\end{array}$ & $\begin{array}{l}\text { TOR } \\
\text { Score in } \\
\%\end{array}$ \\
\hline 1. & Volkswagen & 33.92 & 29.69 & 17.99 & 573000000 & 29.57 & 27.20 \\
\hline 2. & Hyundai & 22.72 & 19.76 & 7.97 & 560000000 & 19.64 & 16.82 \\
\hline 3. & KIA & 31.04 & 15.12 & 12.95 & 526000000 & 15.19 & 19.70 \\
\hline 4. & Škoda & 23.36 & 11.75 & 25.42 & 62400000 & 11.84 & 20.18 \\
\hline 5. & Peugeot & 21.76 & 10.56 & 16.56 & 473000000 & 10.60 & 16.32 \\
\hline 6. & Dacia & 17.28 & 4.32 & 2.55 & 106000000 & 4.30 & 8.05 \\
\hline 7. & Opel & 31.68 & 3.98 & 2.39 & 361000000 & 3.97 & 12.69 \\
\hline 8. & Mazda & 12.16 & 2.77 & 7.21 & 464000000 & 2.80 & 7.38 \\
\hline 9. & Suzuki & 23.04 & 1.10 & 2.26 & 630000000 & 1.10 & 8.80 \\
\hline 10. & Mitsubishi & 41.28 & 0.96 & 4.59 & 553000000 & 0.99 & 15.61 \\
\hline
\end{tabular}

Source: own processing

Firstly, we focused on analyzing the reputation of the selected business entities using broad sentiment analysis. For each analyzed subject we took into account the first ten results after typing in the selected keywords - name of the brand - in the search engine Google. The first results featured, as expected, brands' own websites followed by websites with predominantly 
neutral character. A link to the online encyclopedia Wikipedia and links to profiles on virtual social networks were marked as having a positive sentiment. Interestingly only two brands showed negative results in the search engine. Then, we added to the name of the brand another keyword - "Slovakia". This keyword significantly increased the incidence of positive sentiments (as well as negative in selected cases) in the search results. Except for the brand Škoda, all subjects showed at least one positive sentiment.

In the second step, we analyzed the dominant determinants of reputation focusing on profiles on the most popular virtual social networks/media. We found that each of the analyzed business entities actively uses localized channels on YouTube. Each of the analyzed entities uses the social network Facebook to implement their marketing activities (although this medium is in terms of e-marketing considered a necessity). Although the language and content localization are sufficient, the efforts are insufficient given the trend.

In the third step of our analysis, we calculated the overall reputation. The clear winner is Volkswagen, Škoda and KIA, which showed the best results among all the studied subjects. The following figures will show some interesting facts resulting from the analysis.
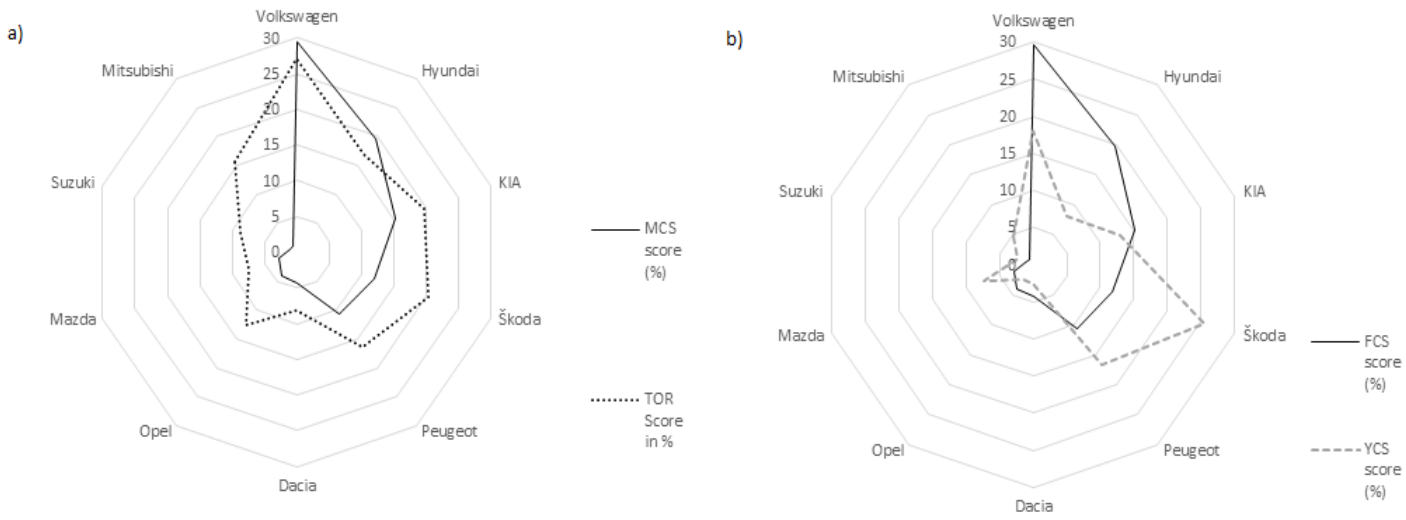

Figure 1: (a) Market share vs. Overall Online Reputation; (b) Activity on VSN

Source: own processing

Figure a) compares the market share of brands from the point of view of the strength of their total virtual reputation. Figure b) shows the power each brand has on the social network Facebook and YouTube in terms of fans/followers. With regard to the overall reputation and the total market share of the brand, figure a) clearly shows that the Volkswagen Group duo does the best work among all the studied brands. Based on the analysis' results we began with statistical testing of the selected context. Regarding the correlation between the market share and the level of the overall virtual reputation, the $p$-value is more than 0.05 (the significance level of $5 \%$ ). Thus, we can reject the existence of a statistically significant connection between the variables. With regard to the correlation between the scores given by the sentiment analysis and the total number of Google index pages regarding the business entity, we can conclude that the $p$-value is less than 0.05 (the significance level of $5 \%$ ). Thus, we were able to confirm a statistically significant correlation between variables.

\section{Conclusion}

From the point of view of researched subjects, brands in the leading positions have a distinctive advantage in terms of their online reputation among Internet users. In case the user seeking information about a particular subject does not encounter positive reputation indicators, this can ultima tely affect his/ her overall perception of the entity. Brands should attempt to curb negative publicity, and vice versa, to enhance and work on positive publicity. This can be achieved 
particularly through the active online communication policy like dissemination of positive information through renowned major online newspapers or social networks. The best way to remove negative or neutral publicity in the first ten search results is a literal displacement of negative publicity by a thoughtful marketing communication policy conducted in the online environment. In general, it would seem that the most effective model of the comprehensive online reputational management is to focus on dominant reputation determinants. Active instruments of the online reputational management can greatly facilitate active communication with the public, help in acquiring and evaluating feedback or speed up implementation of measures related to a crisis marketing communication. Without a strong base of users, none of this is possible, not with a significant result. What can we state in the end? The comprehensive analysis provided comprehensive results. Despite the limitations (local market conditions) we would like to state that the resulting comparisons and formulated interpretations provide a realistic and comprehensive view of the market of automotive sector focusing on the Top 10 local car brands. The offline world represented by traditional players as newspapers or magazines largely affects the reputation of selected entities, especially among professionals. Given the specificities of the time (and the number of other research and analyses), we want to state that the general public, generations $X$ and $Y$, is affected by those traditional players in terms of reputation shaping to a limited extent. The center of their information world is the Internet. Another trend of the times, the move away from mainstream information sources to alternative media and community portals makes it harder to control one's reputation. Search results on Google in the form of links to fan pages, community forums, catalog portals or local media can reveal even smallest imperfections in marketing communication. In combination with Facebook and Google ratings in the form of stars, a single person can destroy the reputation of a company. The strength of that person's "marketing" message is enforced through authenticity that this message carries and making it look legit. Our research synthesizes all mentioned view points and offers a clear comparison of reputations of analyzed subjects across both worlds (online and offline). The results (processed graphically) bring interesting findings worthy of greater consideration.

\section{Acknowledgments}

This work was supported by the Slovak Research and Development Agency under the contract No. APVV-15-0511.

\section{References}

- Delina, R. (2014). Transparency in Electronic Business Negotiations - Evidence Based Aanalysis. In: Quality Innovation Prosperity. Vol. 18, No 2, pp. 79-89

- Delina, R., Dráb, R., (2009). Trust building on electronic marketplaces in the field of escrow services and online dispute resolution. In: IDIMT-2009 System and Humans-A Complex Relationship. Linz: Trauner, 2009. Pp. 149-156.

- Delina, R., Tkáč, M., (2010). Trust Building Mechanisms for Electronic Business Networks and Their Relation to eSkills, World Academy of Science, Engineering and Technology 6 (71), pp. 380-390.

- Dorčák, P., Markovič, P., Pollák, F. (2017). Multifactor Analysis of Online Reputation as a Tool for Enhancing Competitiveness of Subjects from Automotive Industry. In: Ekonomický časopis (Journal of Economics), 2017. Vol. 65/2017, No. 2, p. 173-186.

- Dorčák, P., Štrach, P., Pollák, F. (2015) Analytical view of the perception of selected innovative approaches in marketing communications. In: Quality. Innovation. Prosperity=Kvalita. Inovácia. Prosperita. Vol. 19, No. 1 (2015), pp. 74-84. Crossref

- Fertik, M., Thomson, D. (2010). Wild West 2.0: How to Protect and Restore Your Reputation on the Untamed Social Frontier. USA: Amacom.

- Fill, C. (2009). Marketing Communications: Interactivity, Communities and Content. 5th Edition. UK: Pearson Education Ltd. 
- Gottschalk, P. (2011). Corporate Social Responsibility, Fovernance and Corporate Reputation. USA: World Scientific Publishing Co. Pte. Ltd. Crossref

- Helm, S. et al. (2011). Reputation management. Berlin : Springer-Verlag Crossref

- Kanika, D. (2016). Prečo je online reputácia dôležitá? [on-line]. [2017-04-10]. Available at: <http://www.pranswer.com/sk/manazment-povesti-referencie-a-recenzie/preco-jeonline-reputacia-dolezita/>. (Slovak)

- Leboff, G. (2011). Sticky marketing - Jak zaujmout, získat a udržtet si zákazníky. Prague: Management Press. (Czech)

- Maryška, M., Doucek, P., Novotný, O. (2012). Requirements of companies on the knowledge ICT specialists for the ICT administrator role. 4th World Conference on Educational Sciences. Barcelona, 2012. Procedia - Social and Behavioral Sciences. Vol. 46 (2012), pp. 4389 - 4393. Crossref

- Maryška, M., Doucek, P., Kunstova, R. (2012). The Importance of ICT Sector and ICT university education for the economic development. 3rd international conference on new horizons in education - INTE 2012. Vol. 55, pp. 1060-1068. Crossref

- Marsden, H. (2013). Guard Your Reputation On-line. Birmingham: Smartebookshop.

- Pollák, F. (2015). On-line reputačný manažment v podmienkach stredoeurópskeho virtuálneho trhu. Prešov. Bookman. (Slovak)

- Pollák, F. et al. (2016). Sustainable E-marketing of Selected Tourism Subjects from the Mediterranean Through Active Online Reputation Management. In Volume 166 of the series Lecture Notes of the Institute for Computer Sciences, Social Informatics and Telecommunications Engineering, Berlin: Springer. pp. 692-703. Crossref

- Pollák, F., Belovodská, K. (2015). Multifactor analysis of online reputation as a tool for enhancing competitiveness of selected health care providers, In Annual international conference on enterprise marketing and globalization, Global science and technology forum, Singapore. pp. 6-12.

- Sasko, J. (2014). Dbáte na hodnotu svojej značky? [online]. [2015-03-12]. Available at: http://www.podnikaite.sk/manazmentmarketing/c/1392/category/marketing/article/onlinereputacny-manazment.xhtml

- Soviar, J. (2011) Simplification of Marketing Scheme for Business Start-Ups. In Communications - Scientific Letters of the University of Zilina, Vol. 13, No. 4.

- Soviar, J., Vodák, J. (2012) Value network as part of new trends in communication. In Communications - Scientific letters of the University of Žilina, Vol. 14, No. 2.

- Stradtman, L. R. (2012). Online reputation management for dummies. John Wiley and Sons.p. 384.

- Stec M., Filip P., Grzebyk M., Pierścieniak A. (2014) Socio-economic development in EU member states - concept and classifications, Engineering Economics, Vol. 25, No. 5. 